\title{
Strategy for Resolution of the Organic Complexant and Organic Solvent Safety Issues
}

\author{
J. E Meacham
}

Dince Putristised

June 1996

Prepared for the U.S. Department of Energy

Assistent Secretery for Emvironnertat Mantegement

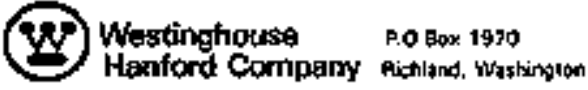

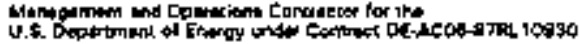

- Approved for publlc release; distribution is unlimited 


\section{RELEASE AUTHORIZATION}

Doctment Nunber: WHC-EP-0908

Document Thle: Strategy for Resolution of the Organic Conplexant and Organic Solvent Safety 15sues

Reloves Dete: $\quad 6 / 27 / 96$

This document was reviewed following the procedures described in WHC-CM-3-4 and is:

\section{APPROVED FOR PUBLIC RELEASE}

Whe Informution Rutoaso Admintittration specialiat:

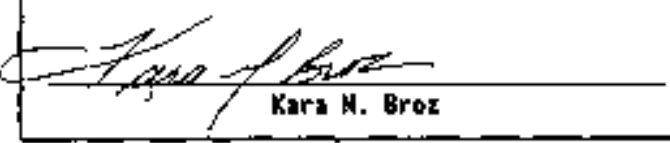

June 27, 1996 


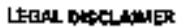

The repon wat propaised at on abcount of wak ppanaaiad by

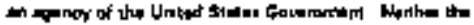

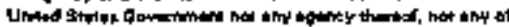

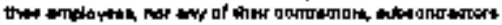

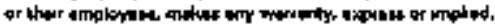

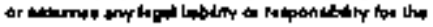

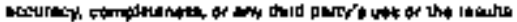

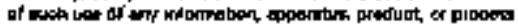

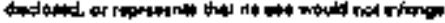

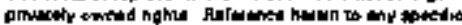

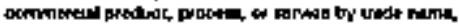

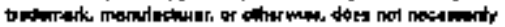

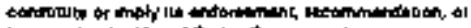

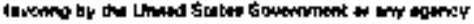

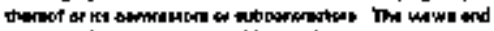

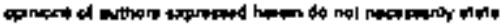

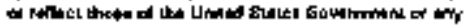
mancy onemod

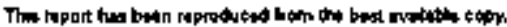

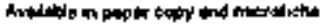

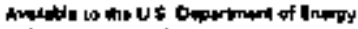

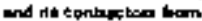

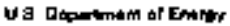

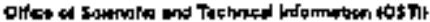

ค Q Bay az

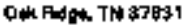

18151570 0401

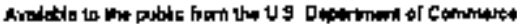

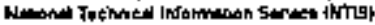

52A5 Fon Row Ford

tpnnghidd, va $21 \% 1$

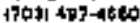

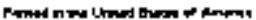

Cesard 1 CHF is ibs 
THIS PAGE INTENTIONALYY LEFT QLAAK 


\title{
STRAFEGY FOR RFSOLUTION OF TJEE ORGANC COALLEXANT AND DRGANIC SOLVENT SAFETY ISSUES
}

\section{ERECUTYVE SUMRARY}

\begin{abstract}
A basic strategy and logic for resolving the orgaric complexant and organic solvent safery jsones ane presented. Interim safe storage can be entoured in ont of three ways: (1) demonstrate through theory, modeling, safjpling, and testing that the wraste lackss sulficient fued to combust; (2) show through modeling and monitoring that the waste containts

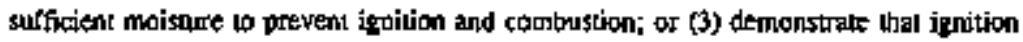
sources are adequalely controlled. Mitigation is required if controls are deemed tradequate.
\end{abstract}

Prestently, no singlo alternalive is believed gufficient to ensure interim safe storage for all orpanie tanks. Therefore, activjlies for al three alerbauives are summarlzed in this strategy. 


\section{CONTEYTS}

1.0 INTRODUCTION . . . . . . . . . . . . . . . . . . . . I

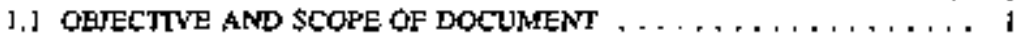

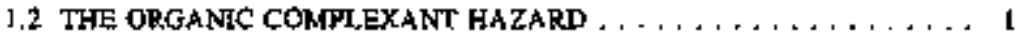

1.2.1 Headspace Flanmabilliy $\ldots \ldots \ldots \ldots \ldots \ldots \ldots \ldots \ldots, \ldots$ I

1.2 .2 Spontanoous Chemical Rurnuay $\ldots \ldots \ldots \ldots \ldots \ldots \ldots \ldots$ J

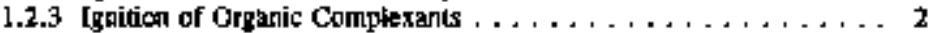

I.3 THE ORGANIC SOLVENT HAZARD $\ldots \ldots \ldots \ldots \ldots \ldots \ldots \ldots$.

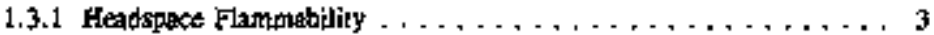

1.3 .2 Sprontaneous Chenical Runaway $\ldots \ldots \ldots \ldots \ldots \ldots \ldots 3$

1.3 .3 Iprition of Organic Solvents $\ldots \ldots \ldots \ldots \ldots \ldots \ldots \ldots \ldots$

I.4 CONDITIONS NECESSARY FOR CONEUSHION $\ldots \ldots \ldots \ldots \ldots \ldots$. . .

2.9 STRATEOIC LOGIC FOR RESOLUTION OF THE SAFETY ISSUFES . . . . . 4

3.0 CRTERLA FOR SAFE STORAGE $\ldots \ldots \ldots \ldots \ldots \ldots \ldots \ldots \ldots$

3.1 ORGANIC COMPLEXANT CRITERIA $\ldots \ldots \ldots \ldots \ldots \ldots \ldots 7$

3.2 ORGANC SOLVENT CRTERIA $\ldots \ldots \ldots \ldots \ldots \ldots \ldots \ldots$

4,0 WASTE PHENOMENOLOGY $\ldots \ldots \ldots \ldots \ldots \ldots \ldots \ldots \ldots$

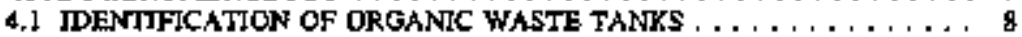

4.1.1 Historical Records . . . . . . . . . . . . . . . . . \&

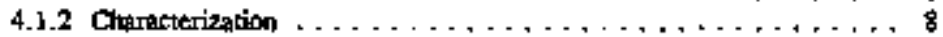

4.2 FUEL CONCENTRATJON $\ldots \ldots \ldots \ldots \ldots \ldots \ldots \ldots \ldots$

4.2.1 Proporating Combuscion Tesuing . . . . . . . . . . . . . 9

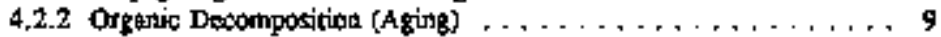

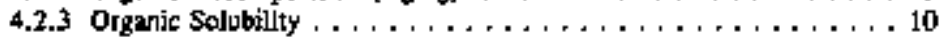

4.3 MOISTURE CONCENTRATION . . . . . . . . . . . . . 10

4,4 JGNITION REQUIREMENTS $\ldots \ldots \ldots \ldots \ldots \ldots \ldots \ldots \ldots \ldots, \ldots \ldots$

4.5 RISK ANALYSIS $\ldots \ldots \ldots \ldots \ldots \ldots \ldots \ldots \ldots \ldots$

5.0 MONJTORING AND MTIIGATION $\ldots \ldots \ldots \ldots \ldots \ldots \ldots \ldots$ 1]

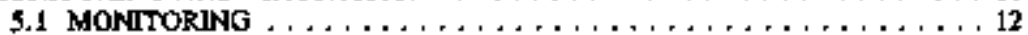

$\$ .1 .1$ Temperature and Pressure Montitsing $\ldots \ldots \ldots \ldots \ldots \ldots 12$

5.1 .2 Mojsture Monitoring $\ldots \ldots \ldots \ldots \ldots \ldots, \ldots \ldots, \ldots \ldots$

5.2 MHTIGATION $\ldots \ldots \ldots \ldots \ldots \ldots \ldots \ldots \ldots \ldots, \ldots \ldots$

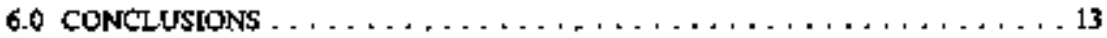

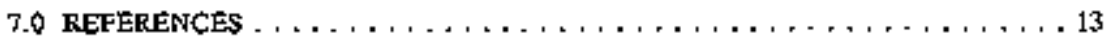




\section{LIST OF FJGLRES}

1 Strategy for Resolution of the Organic Safery Issues $\ldots \ldots \ldots \ldots \ldots \ldots \ldots$

\section{LEST OF TERMS}

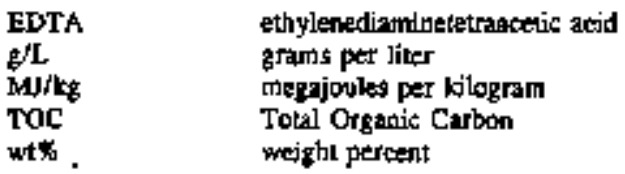




\subsection{INTRODLiCTKON}

\subsection{ORJECTIVE AND SCOPE OF DOCUMENT}

The objective of thig document is to describe a general strategy for the regolution of the organic solvent and complexant safely issues. The strategy is comparable to the best practices in the chemical and petroteum industries (American Institute of Chemical Engireers 1989. 1992, 1995a, 1995c, 1995d, 1995e) and is applitiale for atl tanks with organic complexants andipr organic solvents. The scope of the stralegy is limited to isterm stacic storape and does not include dynamic operation such as retrieval or disposal operations.

\section{I.2 THE ORGANHC COMPLEXANT HAZARD}

During the defertse mission at the Hanford Site, organic cormplexants ineluding glycalie acid, citric acid, hydroxyethylethylenediamirescracetic acid, and ethylenediamistetratapetic acid (EDTA) Were used during fuel reptocessing, methl recovercy optrationts, ayd waste nathagement separations. These matrjials were discharged to the tarkg, where they mixed with sodium bydroxide, sodium nitrale and nitrile, and other inorgentic diluents already present in the tankz. In the presence of oxidizing materials, such as qitrates or nitrites, orgaric complexants can be made to teacl exolhermically by heating lo high lemperanures (above $220^{\circ} \mathrm{C}$ ) in by an jnitiator of sulficient energy (Fauske et al. 1995). Three hazants have been examdned for orgatic complexants: (1) headspace flatemability; (3) sporsianeouss chemical runaway (telf beatng) reacliont occurring throughout the waste mass; agd (3) igrilion of propagating exothermic chemical reactions (coptoustion) typified by a moving resction fropt.

\section{2,1 Headspace Flammability}

Although decomposition of organic complexants can generate flamrable gages, orgaric complexant salts themselves are nonvolaule and exert no vapor pressute. Thus, orgentic complexant sallts are nol a hesolspace Aammability hazand in Hanford Site waste tanks.

\section{2 .2 Spontaneous Cliennical Runaway}

The rate of healing must exceed the rate of cooling for a spontaneows chemical nungway reaction to occur (Gygax 1990). If the temperanure is not controlled, then undeslabie deflagrations cagn oocur when the large activation extergy barriers ate excesded. Pteventing sponianeous cherrical sunzway fas been thoroughly studjed in the chtemical asd petroleum industries (Americen Institure of Chemieal Enzirsens 1989, 1992. I995a, 1995b, 1995e, 1995d, and 1995e). Harford Site lank w'astes have been assessed using sienilar methodalogy (Fauske I996). 
The portential for a spontenceus chemiçal ruoaway reection was cvaletated by comparing the cheracteristic time of copling fi.e., the time required to reach a new equilibrium tempersture followigg an instantaneous change in heating jace) will the waste storage time. Calculations jotdicale thal the characteristic tirne of coding ranges from a few hours to $\mathbf{3 . 1}$ years tor the Hanford Sile tanks (Fauske 1996). Some waste has been stored for more than 40 years, ard there have been to transfers of waste into the single-shell tanks for about is yours. \$twint characteristic tumes of cooling have passed duriag the lasc 15 years of slorpge; consequently, bulk ructawsty reactions are highily untikely to be a hazant under current storape conditions.

In asdition, to eredible mexbenitoms to increase tank temijerstures to chemical nenaway reaction levels have been idemifito. Drying the wastes can decrease the thermal conductivity; however, this docrease wopId not be sufficient to lead to spontaneous chemical runaway (Fauske 1996). Waste tempesatures afier removal of the pumpable llaquid (interim. stabilizatlong have contitued to decline consistent with the principal hest losd from radiogctive decay rales. One hundred fourteen of the 149 single-shel] tanks heve beer interitus stabilized.

\subsubsection{Jguiton of Organic Complexants}

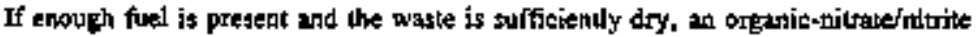
propagating combustion event could be ind lated by a varkty of sources. Polchtial medible iguition soures indude hot ijetal cbjocts, kotary corc upsetg, buking gasoline spills from a rugtured vehicular tuel tank, or lighturing (Webb et al. 1995). An organic complexant

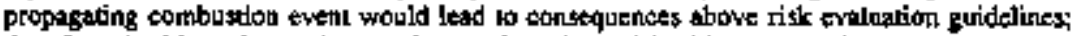
therefore, ienition of ofgante complexants is addressed to this strakefy document.

\subsection{THE ORGANIC SOLVENT HAZARD}

Vations separalion processes involving organic solvents have bectis used at dre Hanford Site. These organic golveris wers iqadventently axdion parposely sent to the underground storage poks, and subseguetr waste transfer operations might have disenfuled organic solvent anong stwedal of the 177 high-Jtwel waste tanks at the Hanford \$ile (\$edertosrs and Reddick 1994). The priacipal orgastic solvents are tributyl phosphale and mixtures of notmal parafinic hydrocabons. The solvents ate onty parially soluble in the aqueous wastes and an therefare exist either in separate plaser dispersed among obtes biquid and solid phates on in a separate layer atop the aqueous phase. Thwee potential hazards have been idealifiod for organic solvents: (1) contribution to headspoce flammability; (2) spontareous chemical runawsy; and (3) ignition of organic solwents thal are entrained in the waste or pooled on the Hatate striface. 


\subsubsection{Fieadspace Flommabllity}

Al current tank temperatures, the organjc solvent yapor contribution to headspace flammability is tow (Claybrook and Wood 1994). Host of the orgaric solvents matraining in the tanks have low vapor pressures. Sampling data fiom all tanks sampled to date supports this conctusion (Hutkaty et al. 1995). Otgatic solvent vapors in tark 241.C-103 (which contains a floalting orgaric solvent layer) amount to less that 5 g w of the lower flammability limit (Huckaby and Story 1994, Postrya el al. 1994). Conseguently, organic solvents do mot constitute a headspace flammability hazard as presentiy slored in the tanks.

\subsubsection{Spouteneaus Chemical Runakay}

As discutssed in Section 1.2.2, the petentiad for spontaneous chemical runaway has been assessed for the Hanford Site lante (Fauske 1996). Several characteristic times of conling have passed during waste storage, and bulk nungway renctions are not a bazard under current storage conditions. This conelusion is applicatale whether the fuel source is pratinice cormplerants or organic solvents.

\subsubsection{Jution of Organde Solvents}

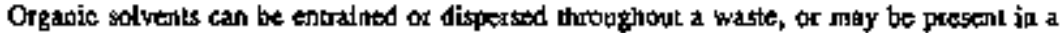
separate layer. If a portion of the otgatic solvent were heated to the flash point by a large initiansar, combustion in gir would ensus. An orzanje golvent contoustion might lead to consequences abowe risk evalustion guidelines (Posima et l. 1994); thesefore, ighition of argante solvents is addressed tn Utis strategy document.

\subsection{CONDITIONS NECESSARY FOR COMBUSTION}

An organic solvedt of organic somplextill combustion event carnot occut unless axygern (oxidizer), fuel, and temperahure (initintors) are al] present in sufficient amounts. Becouse all Lhree condtitions must be sufficient for a reation to oceur, waste esh be stored safely if one

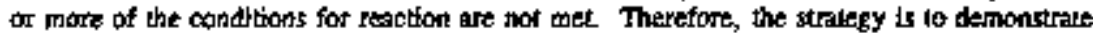
that one of the conditions of fuel, oxidixer, or temperature (initiators) is rot sufficitent or thal at teast one condition is cootralled or mittgated.

If sufficient fuel and oxidizer are presed, molsture can prevett combustion of organie complexenls. Moisture prevents combuslion by two main mecharisms: (1) molsture behaves Bs an inert tiluent (lowering the effective fuel consentration); and (2) moisture provides a large hest sink that innibisis igojtion and propatathon. For a reactlon io propagale, enough energy must be supplied to overcorre the sensible and laterit heal of the moisture present. 
Small ignition sources such as sparks, inipacts, and shocks lack sufjkient enesgy to iniuare an organic conplexant or orgenic solvent combustion. Credjble josilion sourcts bave been natroued to only sobust or suspained energy sourtes. Administrative contods have been implemented in the tank farms Io reduce the potential to jntroduce janicion sources (WHC 1996). Controis will remain in place on a tank until remosal of the controls can be technically justified.

\subsection{STRATEGIC LOGIC FOR RESOLUTION OF THE SAFETY ISYUES}

The strakegie logic (see Figure 2-1) for fesolation of the safety issues is comprised of four etertionts.

- Element 1. Idenlification of the applicable oryanic sefety issus. This element of the strategy was digeussed in Section 1.0.

- Eement 2. Identifcalion of irileria and conditions under which the wastes can bo saftly stored. Saft scorage criteria are discusstad in Section 3.0.

- Elemeat 3. Theory, modeling, sampling, and testing are used to develop an uddersanding of weste phenomendosy. The techrical inforrtation is critically cvalualed in a risk-based agsespnem to deremine the safety stalus of the waste, and the lanks are calegorized as sogfe, complitionally roffe, or witrofe. \$pecific tasks that examine wagte phenomenology are lisied in Sectlon $d, 0$.

- Elemepl 4. The safery issucs are resolved by demonstating one of the following: (1) the wate lacks sufficient fuel concentration for a propeg fating combustion; (2) the waste retains ufficient moisture io prevent a propaganing combustion; or (3) credible

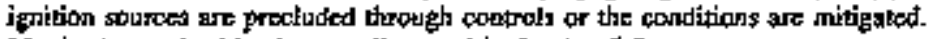
Monitoriato and mitipationt are discussed in Section 5.0.

Prisently, it is not possible to sule oul that any given tant with be placed in one of the three categorles. Therefore, ativities for all bree eventualities are presented it this strategy. 


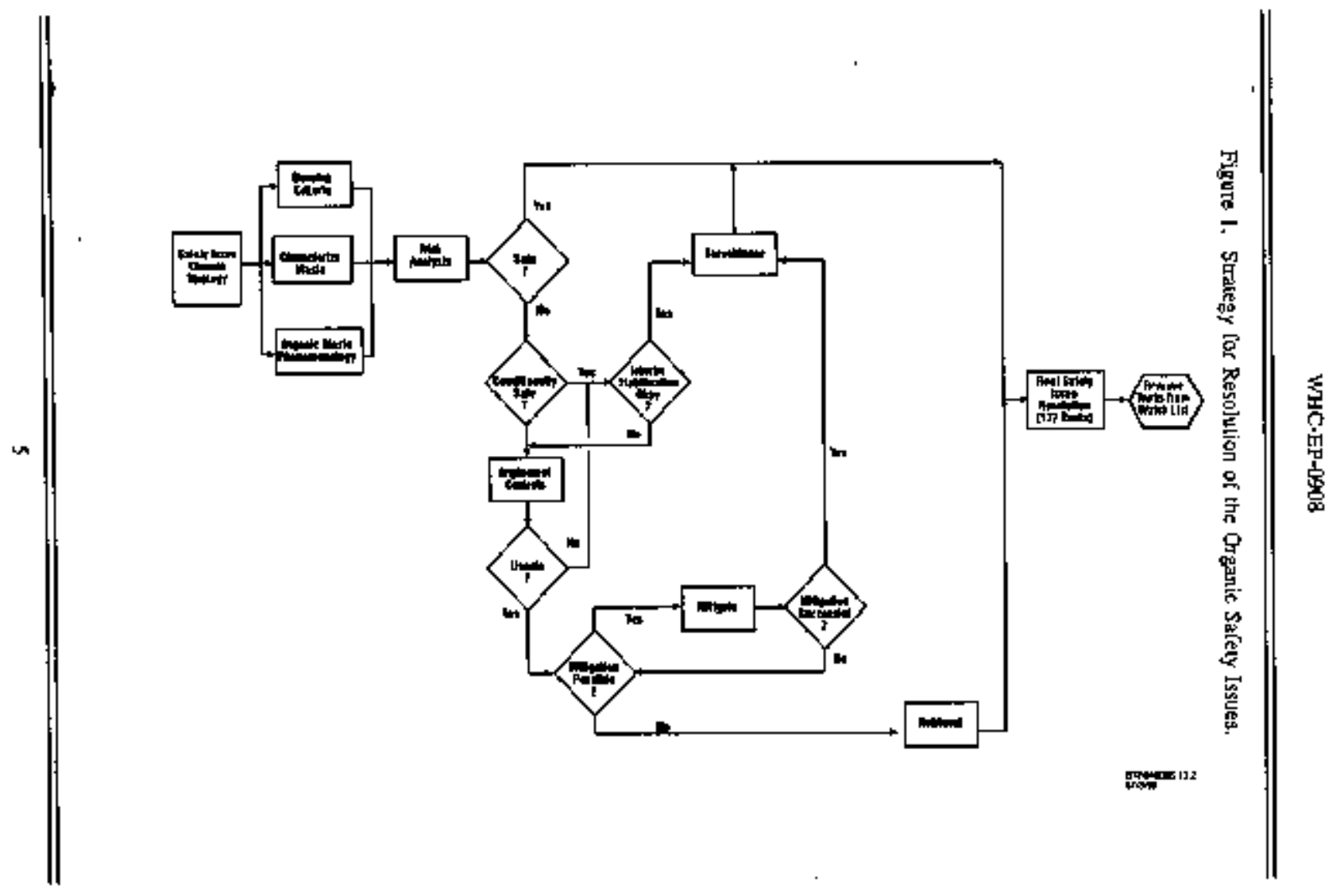




\subsection{CRITERLA FOR \$AFE STORAGE}

\subsection{GRGANTC COMPLEXANT CRITEkIA}

Specific conditions of fucl, moisture, and itenperature (injlialors) are all recquired in order for a propagating copibustion event to occur. Based on an initial evaluation (Babad and Turnes I993), the current fisel and moisture criteria are 3 wt\% total organic carbon (TOC) and $17 \mathrm{m \%}$, respectively. However, recent theoredcal analyses and experituents with wi,5te simulants indictate the raintmern fuel conçentration is constiderably highter (Fauske ef al. J995).

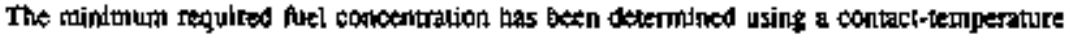
ignition model (Fmske et al. 1995). Experiments with waste simulant indicate that a necessary (but not sufficient) condition for a condensed-phase propagating chemical reaction is thai the fucl concentration be greater than 4.5 w1 5 Toc $(1.2 \mathrm{MU} / \mathrm{kg}$ on an energy equivalent basig). For fuel concentrations between 4.5 and $7.9 \mathrm{w1} \% \mathrm{TOC}$ (dry basis), the waste moishure concentration tequired to prevent a propagating certbustion yaries linearly from 0 b 20 wts. Above 20 with, the fuet-motsture linear relationship no longer folds besause the raixture becomes liquid contimurus. A stolchiometric fuel-oxidizes mixnire will not propagate when the moisture coneenuration exceeds 20 wis (Fauske et bl. 1995). These

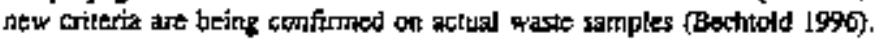

In surmmary, safe storage can astured if the following intequalitles are met (Equations 1 and 2):

$$
4 \times \text { TOC } \leq 4.5+17 x_{4}
$$

or in terms of energy $(\Delta \mathrm{H})$

$$
\Delta H\left(M H / \mathrm{kg}^{\prime}\right) \leq 1.2+4.5 \pi
$$

Where $x$, ts the masg fraction of watec for values less than 0.2 (20 wix).

\subsection{ORGANIC SOLVENT CRITERIA}

Experiments and analyses have improved understanding of the phenomkna associated with potential organte solwent combustion in Hanford Site tanks (Fauske 1996). Results of the experimepts indicate that the organic solvents iumently in Hatsford Site tanks are difficult in ignite. Credible ignition sou:ces bave been narround to robusl andior sustained energy sources. 


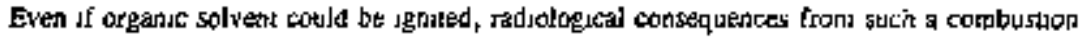

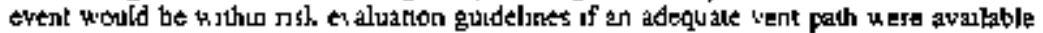
The vent reguluements are dedermined by companng calculated theadispace pressure uncreases to tank destgn presoure An organc solient combustion event would heat lark beadspace gases and pressinze the lark The combustogn evert would contanue unal the ox yren pas depleted The pressumzatron from a postuledtad combushon ewent would inereage with the

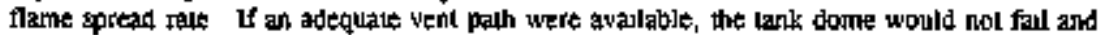

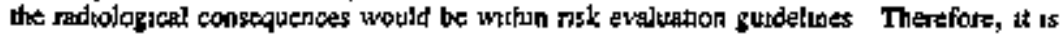
desired to identufy which lanks inght contain the equivalent of a one-yquare-meter or larger pool of argeric solvent

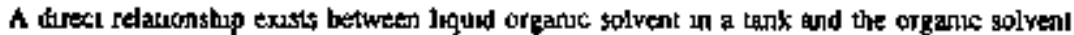
vapors found in the heodspace. The mass transfer of a semivolatule tpectes in an organc inquid (e 8 , dodecase, undecane, or unburtyl phosphaie) to the hadspact vapoin is determuned by several parameats, includung tempierature, the mass transfer coefficient, gas-liquid contact area, vemutaton flow rale, and beadspace volume Uf orpanic solvent is present, organis solvtat vapors should be delectable in a tank besdspace, even if the taik is actively

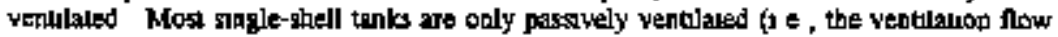
rale Is quite sraal), tbus, the organce solvent vappors should be present at aboul equilbnum

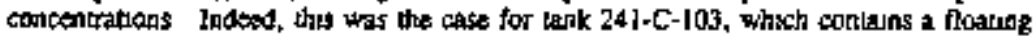
organic solvent pool (Huckaby and Story 1934)

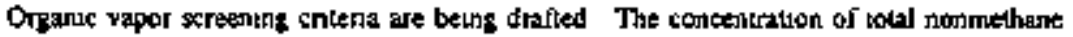
hydrocaboss will be measured and compared to the couceutation antucpated from a ajtesquare-meter pood at lemk Iemperature If the total nonmethane bydrocation concentranon conterion is exceeded, them the reciured yeat path area will be calculated The vent path ares will be checked actanst this calculatron, and if the botual vent paih area is

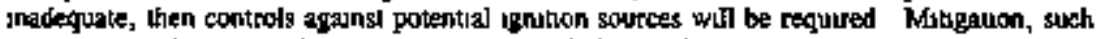
as jncreasing the vert path arch, whll be required if contolls are decomed unadoguate

\section{4,0 WASTE HENOMIENOLOGY}

Waste phenomenology will be assessed using mary sources of information In addibon to the unformatupn generalod when the organk safety progeram, new research programs on the

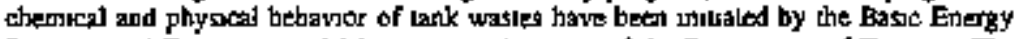
Scienkes and Enviconmental Magagement divisions of the Departipent of Encrgy Thi uformalion wall supplensent the informateon denved fram the activities described th this sectiol] 


\section{I IDENTLICATEN OF ORGANTC WASTE TANKS}

Onte of the most challenging tasks In the resclution of the sefery issues is the accurate jdentification of the ortanic kanks. No singie approgch appears qufficient to jdentify organjc tanks, but a combination of information sources can be used is achiteve this geal. Orpanic tanke are being ldentified using historic dats, waste transfer reconds, watle processing dasa, and recent sampling dala (headspace vapors and condensed phasc). Information will be examined on a tank-by-tank basis or on a tarm-by-farm basis to decermine whether a tank or 2 group of tanks contains sulficient organic material to te defemed a potential thazard.

\subsubsection{Histariol Records}

Historical sampling data, waste transter records, and waste prosessing dala ate being systematically evalualed lo develop organic content modets (Toch et al. 1995, Wetb el al. 1995; A entew 1996). Some of the work provides scoping inforrtation regarding the guanlity and type of malenisl that was purchased and used al Hanford. Other informatican provides. ayerages of the types of wastes that were diapessed to differtent lank fourns, lo sorde instances, detaibed information concerning the stubstances that were discharged into a particular lank are available from process dal (Agnew 1996).

Modeling aetwities will comlimue to exariat tank grouping scherreg and organic concentration ettimatey. Gentratized conctusions on waste conditions may be appsopriale within a waste type, wilhin a tark, or across a famlly of similar anks, fepending on the model and the eonfidente in the model. Madels will be benchroarked trough sampling and characterization.

\subsubsection{Characterinaton}

The 1otal organic cartion cantent of nany of the Hanford Site wasies has been measured in the pasi, and adchtional puessurements will be made during the current charactedation progersm (Turner od al. 1995). The exotherthic energy compenteration and moistare ponsertration of the waste will also be measured. These ineasurements do not discriminate among the differemt organic species found in the wastes, but these two parnfreters are central to the igntion and conbustion tharacteristict of the waste.

The enefgy content of bre principal waste constingehis has been evalualed theoretteally and empirically (Burger 1993, Scheele et al, 1995, Fauske 1996). These are large differences in the energy liberated and the propagating oombustion behavior of the different organic tnolectles. For example, EDTA is a relatively energetic species; however, radiolysis degtroys this malerial under waste storage conditions. By contrast, sodium oxalake 
(a relaliyely long-lived product of radiolysis) has a low enefgy content and cansol support a propagatiog combustlon teven Under stoirchiometre tondilious (Faurke et a. 1995).

Therefort, future wotk will include combustion testing and organic shemical speciation of actual waste. These data will be used to corroberaie organic aging and solubility modeds.

\subsection{FUEL CONCENTRATION}

\subsubsection{Propagating Combustion Terling}

Consistent with procedures developed by the American Instiute of Chemiteal Engineers, the energy concentration of actual weste will be sereened by differential scansing calorimetry and determined by adiabatic calorinetry. If screening defisilely indteates that exothermite decompotition of the waste bas oceurted, then addiional measurements will be conducted using adiabatic caloximetry.

The reasons for adiabatic calorimetry testing are tuofold. Firsl, relatively large samples (five grans or more) are tesued; results from larger samples prowlde grealet assurance thal the sampie tested is representative of the bulk of the simplad material. Second, the pogerved xelf-heating behavior yields evidence about kinetices and energetics of the reactions in driad waste, and is a direct test for a propagating cosnbustlon. Those materials that proparate Show a dranatic step increase (a sharp peak) in the self heating rate, while the malerials that do nol proparate show a more tradual increase (typical Arthenius behaviot).

W日gte samples from six tarks (241-AN-107, -BY-104, -BY-108, -C-201, -C-204, and -SY-10l) have been tetted by adiabatic calonimetry (using the Reactive System Screening Tool).' None of the wastes kested supponed a propagaling combugtion event. Adiabalic calorimetric measutements be obtained on wiste samples from many trote tants in fiscal years 1997 and 1998 .

\subsubsection{Ortanic Decompositkon (Aglng]}

Studices indicate thet organic complerants and solvente underobo bydrolytic and radjolytic decomposition (aging) under tank waste conditions (Camaioni et sl. 1994, 1995). However, the infiuence of temperature and radiation dose on the rats of these reacthons is not suffīciently defined to guantify aging. Kinetic data for these decomposition reactions are bettro investlgaled using waste simulanis. The composition of actual waste will be examined to corrobtotale esging in the tanks.

'Traftmark of Fauske and Associaies, Inc. of Bum Ridge, Jllinpiș. 
The anouncs of organic clienticals that were transferred iuto the tajls are so large thal the substances fortatd as byproducts may become important constituents of the wasie. Most of these byproducts are unstable and quickby converi to other less reactive materials by radidysis or hydrolysis. However, it is not asstrmed that this situation ptevalls uriverstly. Chemical speciation and propagating combuston testing will also help address thege issues.

Alt available gurveillage records are being examined to assess the temperature and radiation dose histories of the orgaric complexanl wasles. Onee conflmed by organic gpeciation, the agimg model tould be used in conjurtition with the historical data, characterization data, and ather information to estifnale current and future organic concentrations.

\subsubsection{Organic Solublity}

The splubility groperties of organic complexapla (organjc solvents are essentially insoluble) are being investigated (Baney 1994, 1996). Tests with waste strultants indleate that wh the important excestion of sodium oxalate, all the obler sodiuth carboxylate salts and their principal oecomposition products are very soluble in the alkeline supenatant soluthons in the laykg. If the energetic complexants are present in the ron-combustible aqueous phases, then most of the fuel coukd be remowed by islerim stabilization (pungping of the liquid from the lanks).

Superratant solutions from 61 tanks have beep arjalyzed for total orgaric carbon concentration. Ondly five of these tank supernatants had total organic carbon cancentrations grealer than 14 ol (Var Vleet 1993a, 1993). The highest measwred value for total organic carbon was abost $40 \mathrm{~g} / \mathrm{L}$. This value is substantially below the measured solubility limil for the energetic complexaris (EDTA, nilrilotriacetale, giycolate, toccinale, dibutylphosphate. and citrste), which is about $100 \mathrm{~g} / \mathrm{L}$. Therefore, it is anticipated that most all of the energethe complexants are contadned to the ligutd phase.

Additional work on orgaric solubilily is needed to investigate: (1) the influence of high valeme ions; (2) the effect of solution densilies; (3) the itupart of having many organic species; and (4) lhe effect of organophosphate compouods in the liguid waste. Restlis with waste simulants will be confimed through analysits (orgarie spextatim) of actual watte samplet.

\subsection{MOETURE CONCENTRATION}

If sufficitor fuel and oxidizer are available, moisture can pkay a key role in preventing an organic complexant proxagating conbusalion event. Waste that contains greater than 20 wits water cansot suppon a propagaling combustion event, even under stoichionetric fuel-oxidizer conditions (Fauske 15\$6). Alsa, experimetsts on sinbulasts indieste that many of the posteplated ignition sceoarios can be excluded from conslderacion if the surface layes of the waste las nore thas about 5 wts water (Fargle 1\$96). 
Becaust of the importance of moisture in ensuring safe slorage, sundies are underu'ay to determine the factors that govern moisture retertion and dryout of the organic wastes. Important paraneters include the ank breaching rate, relative hubjidicy, and the physicalichemical properties of the waske. Tank breathing ralts will be measured tesing gas tracer studies. Experinents on wasle simulants and aciugl waste samples are tnvestigating the effect of relative humidily on the rale of dryout. These experiments will also determine the flnd (minimum) egultibrium moistute concentration in the wosts, Rogulis wi]l be coupled with theoretical work to develop a prediclive model for moisture concentration.

\subsection{IGNITION REQUIREMENTS}

Tube propagation tesis with waste sufrogales and theoretical analyses hawe shown that jgrition sources greater than thres joules are required to iniliate an organic complexant propagaling combugtion event (Fruske at al. 1995. Fautke 1996). Otgantic solvents are even more Gifficuil to ignite. Bot sieel spberes (up to 270 joults) and an cilctronic match (about 139 joules) [ailed to 1guite organic tolvent simulant (dodseane) during ipnition expertments (Fauskt 1596). \$parts, impacls, and shocks lock sufficient energy to iguite organic complexatis of organic solvents.

It may be possible to show that no credible initiators exist for an organic solvent or orgaric complexant combuslion event, or that the presence of waler greally dimintshes the risk of iniliacion of such reactlons. Thert fore, laboralpoy tests using waste simulants are being conduched to deflye the entrgy requirements for ignition of the dry wastes, and to determinte the minintum wase maisture concentations required to preclude initiation of organic conplexant propasgathing combustions. Work will also tontiue on examining ignition source requiremenls for organic solverl pools and entrined orpanic solverl.

\subsection{RISK ANALYSIS}

laformation from bistorical records, characterization, propagating combustion vating, organic aging experiments, and orgnic solubilify testipg will be crilically evalualed in a rikk based

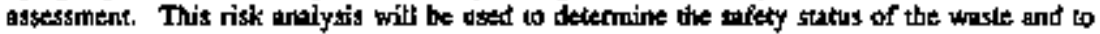

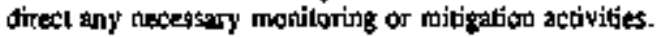

\subsection{MONTTORING AND MITIGATION}

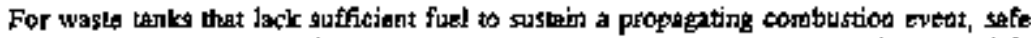
interim sorage can be achieved through prodeat waste majagement operalions orr minimal interial aperational gatery resuirement contcols. Monitaring is gat reguirect for these tajks. 


\section{S.1 MONTTORITG}

If it is not possible to demonstrate that a waste canoot combust, monitoring might be required to confirm interim safe gtorage of organic waste, Monitoring is also required on the 20 organic tarks idebtified in tesponse to the Wyder Amendment (Public Law 101-510, Section 3137 (1990)]. The Wyden Amendment states that "the Sterctary shell determine whelher continuous moniforing is being carried out to detext a release or excesstve temperature or pressure al each tank 80 identified." Temperature and pressure monitoripg are dlscussed below. Because of the importance of motisture, moisture monitering is also distusted below.

\subsubsection{Tempersture and Presure Monitoring}

In the unlikely citcumstance of an orpanic conplexant or organic solvent combustion event. temperature/pressure montioning would detect the occusrence is real lime. Temperaturel pressure manitaring wotld not facilitate interdiction of an event because pressures capable of . conpromising dome integrity are rached in less than one hour (effeclively precluding the possibility of timely interdiction).

Temperature/pressure thoniwhing might, bowever, farilitate timely imptementation of emergency response measures. Therefore, such thonitoring has a sipnificant benefit. For each tank at risk from an event, the stralegy is to haye cilher continuous temperature moratoriag or continuous pressure monitoring.

\subsubsection{Molsture Manftoring}

Moishure can prevent combustion of waste that contains sufficlent fuel and axidizer to otherwise combust. Rourtine, ja sitn measuremanus of the moigtore concentralion of the wasles provido a secure basis for evaluatisg their gafety. Development work will continue on

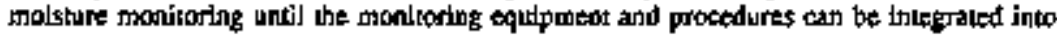
roumal tank farm aperations.

\subsection{MITTEATION}

If controis alone are not adequate to prevent credible jghilios sources from contacting try feactive waste, then mitigation will be required. The simplest intigation stheme is to add water to the tants. However, many of the sinele-sheil tanis are assumed teakers. Therefore, a carefiully enntrolled system for adding the minimum water requited for safety is under development, If mitigation is nol possible, thed retrieyal and temediation are necessary. 


\subsection{CONCLUStons}

Three alcemative jaths for resolving the organic safecy issues are being pursued girwultaneously: (1) demonsurate through theory, modeling, sampling, and lesting that the waste backs sufficient fivel oc combust; (2) show through modeling and monltoring that the urste codtaint sufficient moistore to prevent igrvition and cornbustion; or (3) dermonstrate that

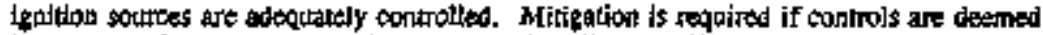
inadoqnale. Presendly, do ainglo altemative is belicved sufficient to ensure interitn ste storage for all organic tanks. Therefore, activities for all three apporoaches are planned. The organic gafety program wrork will continut until the nexesgary oquipment and procedures are integrated into norrol lank farm operations.

\section{7+0 REFERENCES}

Agnew, S. F., 1996, History of Organte Certon in Hayjord HLW Tants: HDW Madel Rev. 3, LA-UR-96-989, Los Alamos National Laboratory, Los Alamos, New Mexies.

American Institute of Chemical Engineers, 1989, Plan Guidelines for Technical Managentent of Creatical Process S4fery. Ametican Institute of Chemical Engintern, New Yark. New York.

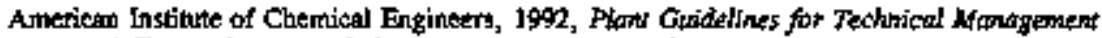
of Chemical Process Safery, American Instilute of Chenical Engineers, New York, New Yoxk.

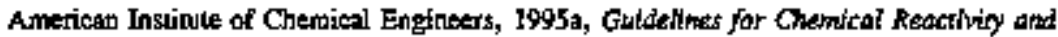
Applifections no Process Destent, Anterican Institute of Chemical Enfineers, New York, New York.

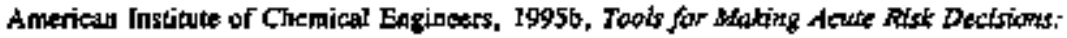
With Chenical Process Applicarions, Aurerican Instilote of Chemical Engineers, New York, New Yort.

Amesicar Inslitute of Chenical Enqineetg, 1995c, Gutdelines for Process Saffey Managenteny, American Institute of Chomical Engiasers, New York, New York.

American Institute of Chomical Enginecrs, 1995d, Guddtines for Process Safery Fusdonterwats for General Plan Operation, American Instibute of Chemical Enciness. New York, New York.

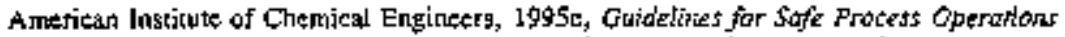
and Moinrenance, American Institute of Chemical Engizers, New York, New York. 


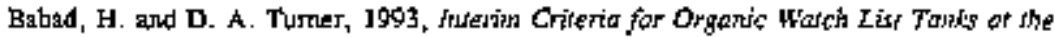
Hanford Stre, WHC-EP-0681, Westigghotse Hantord Company, Richland, Washingston.

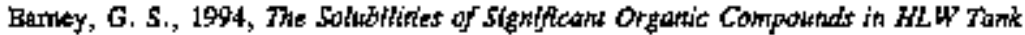
Supemafant Soltutions, WHC-SA-2565-FP, Weslinehouse Hantord Cortjpany, Richland, Washingtop.

Baracy, G. 5., 1596, The Solwbilities of 5ignificant Organic Contpownds in HLW Torth Supermatant Solutiopt-FY]905 Progress Repor, WHC-EP40899, Westinghoust Hasfond Company, Richland, Wastuinglon.

Bechtold, D. B., 1996, Laborawy Test Plan for Meusuring Tank Woste Propagation or SetfHeating Using the PRSST, WHC-SD-WM-TP-438, Rey. 0, Westinghouse Hanford Company, Richland, Washington.

Buryer, L. L., 1993, Cakbutation of Reacrion Energies and Adiabatic Temperotures for Waste. Tank Reacrions, PNL-8557, Pacifie Nonhwest Laboratory, Richland, Wathington.

Camaiomi, D. M, W. D. Samula, B. D. Lenihan, S. A. Clauss, X. L. Wahl, and J. A. Camphell, 1994, Organic Tatkr Safery Progran Fotre Aging Siufler. PNL-10161, Pacific Nortiwest Laberatory, Richland, Washington.

Campioni, D. M., W. D. Samuels, \$. A, Clauss, B, D. Leníhan, K. L. WahI.

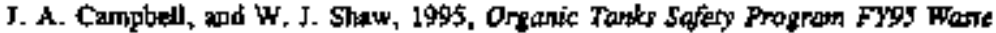
Aging Studies, PNL-10794, Pacific Northuest Laboratory, Richland, Washington.

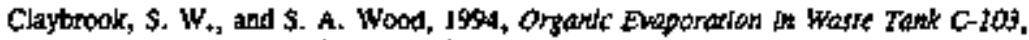
WHC-SD-WM-ER-344, Rev. 0, Westinghouse Hanford Company, Risbland, Washingtun,

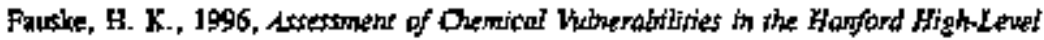
Wagt Tonks, WHC-SO-Wht-ER-543, Rev. 0, Westinghoute Hanford Company, Rickliand, Wastimgton.

Fansice, H. K., D. R. Dickinson, R. J. Cash, and J. E. Meacham, 1995, The Contoct

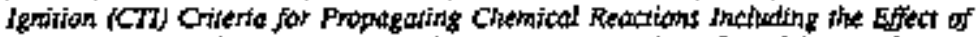
Hoissure and Appticerion to Hargfond Wagts, WHC-SD-WM-ER-496, Rev, 0, Westingbouse Hanford Company, Richland, Washinkton.

Gygax, R. W., 1990, "Scaleup Principles tor Assegsing Thermal kutsway Risks, Chericot Enginetring Progress, February 1990. 
Huckaby, J. L., H. Babad, and D. R. Bratzel, 1995, Headpace Gos and Vopor Characterization Sumutary for the 43 Vapor Proguam Suspecr Tants, WHC-SD-WM-ER-5!4, Rew, 0, Westinghouse Hanford Company, Richiard, Washing cons.

Huckby, J. L., and M. S. Story, 1994, Vopor Charactertzatiot of Tark 24I-C-103, WHC-EP-0780, Rev. 0, Westinghouse Hanford Company, Richland, Washington.

Postma, A. K., D. B. Becktold, 0. L. Bortheim, J. M. Origsty, R. L. Guthrie,

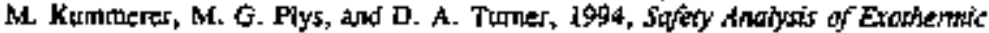
Reaction Razaris Arsociased wifh the Organte Liquld Loyer in Tank 241-C-103, WHC-SD-WM-SARR-OO1, Rey. 0, Westínshouse Hayford Compary, Richland. Wastiniton.

Publiç Law 101-510, 1990, *Safely Meatures for Wase Tanks ot Hanfoud Nuclear Reservalion," \$ection 3137 of Natsonal Defense Althorization Acr for Fiscal Year I997.

Scheek, R. D., J. L. Sobolik, R. L. Sell, and L. L. Burger, 1995, Orgawt Tank Sakery

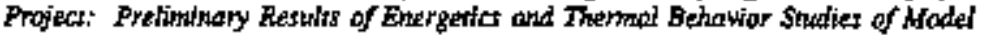

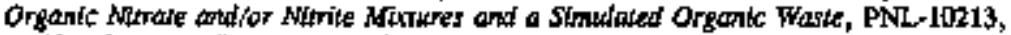
Pacific Norlhwest Laboratory, Richland, Washingken.

Saderburg, J. P., and J. A. Reddick, 1994, TBP and Dipent Mass Batances in the Prarex Pfould ar Hatrord 1,555 + I99I, WHC-MR-0483, Rey. 0, Weslinghouse Hanford Conpany, Richland, Washingion.

Toth, J, J., P. G. Heasler, M. E. Letchen, J, G. HEll, and P. D. Whilney, 1995, Arutlysts of Organde Carbon ond Hoitrure is fanford single-shell Tank Warte, PNL-10360 Pacific Northwest Laboratory, Richand, Washlngion.

Turner, D. A., H. Babad, L. L. Buckley, axd J. E. Meachan, 1995, Duda Quafiry Objective to Support Retolwion of the Organic Complexart Saffety brue, WHC-SD-WM-DQO-006, Rev, 2, Westinghouse Hanford Company, Richland, Washing glot.

Van Vleet, R. J., 19934, Rodionuclide and Chemical Inventories for the Sitgle Shell Torthe, WHC-SD-WMA-71-565, Rev. 0, Westinghouse Hanford Cornpany, Richland, Washington.

Var Vlect, R. J., 19930, Radtonuclde and Chemicol Inventories for she Dowble Shell Tarks, WHC-\$D-WM-TI-543, Rev. 1, Wertinglyoute Hanford Company, Airhland, washltigton. 
Webt, A. B., D. M. Camaioni, J. M. Grigsby, F. G. Heasler, B. Afatinovic, MA. G. Plys, J. L. Stewart, J. J. Toth, and D. A. Tumer, 1995, Prefiminary Sofety Criteria for Organic Warch Lisr Tanks or the Hanford Sire, WHC-SD-WM-SARR-033, Rev. 0. Westinghouse Hanford Company, Richland, Washington.

WHC, 1956, Operaritg Specificarions for Warcy List Tanks, OSD-T-15L a0030, Rev, B-20, Westughouse Barford Company, Rdchland, Washington. 


\section{DISTREUTHON}

Nurmber of copopiss

OEESITE

91 Billy C. Hudson

202 Narthridge Court

Lindsbors, KA 67456

1 Thomas S. Kress

102-B Newridese Roed

Dak Ridge, TN 37339

1 Tromas E. Larson

2711 Walnut Street

Los ALamos, NM 87644

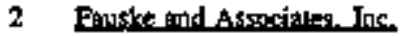
10W070 W. a3rd St.

Burs Ridge, IL 60521

Michoel Epstcin

Fans $K$. Faustre

J G \& $P$ Consolting. Inc.

3600 Ballard Road

Dallas, OR 97339

Adin $\mathrm{X}$. Postma

I Nuciear Consulting Serviges. Inc.

P.O. Bor 29151

Columbus, of 43229-0151

1. Lonis Kovach

2 Sandia NationaLLaboralotis:

P.D. Box 5800

Albuquerque, NM Bribs

Dasa A. Powers, MS-0744

Scott E. \$lezak, Mis-60741 
WHC.EP-OOOS

\section{ONSITE}

Wescinghouse Hanford Company

H. Babad

$57-30$

R. J. Cash

5.7.14

J. M. Grigsby

A3-37

N. iv. Kirth

R2.11

J. E. Meachamn (2)

57-14

D. A. Tumer

Centural Files

S7-14

DPC.

A3-88

A."-94 


\section{THIS PAGE NTENTIONALLY LEFT BLANK.}

